\title{
PENGARUH PENAMBAHAN AMPELA AYAM PADA KOMPOSISI PAKAN TERHADAP PERFORMA REPRODUKSI INDUK IKAN LELE
}

\author{
M.H. Fariduddin Ath-thar dan Vitas Atmadi Prakoso* \\ Balai Penelitian dan Pengembangan Budidaya Air Tawar \\ Jl. Sempur No. 1, Bogor 16154 \\ "e-mail: vitas.atmadi@gmail.com
}

\begin{abstract}
The effect of adding chicken gizzard in the composition of the feed on the reproductive performance of the catfish spawners
\end{abstract}

\begin{abstract}
Currently catfish farming is one of the people's choice, because it is triggered by a number of catfish demand. But in farming activities carried out by people sometimes do not pay attention to the quality aspects of the parent catfish. Parent quality also depends on the quality of the feed given. Therefore, it is needed feed with good quality in order to produce a good quality catfish broadstock. The purpose of this study was to determine the optimum dose of chicken gizzard in feed to the reproductive performance of the catfish spawners. Feed given during gonadal maturation of spawners was floating feed of commercial brands of Hi-Pro-Vite 781 with a protein content of $30 \%-33 \%$ combined with boiled chicken gizzard. The treatment combination of feed used is: 1. Control (Pellet), 2. $25 \%$ pellets, $75 \%$ gizzard, 3. $50 \%$ pellets, $50 \%$ gizzard, and $4.75 \%$ pellets, $25 \%$ gizzard. Parameters measured were fecundity, length of rematurasi, hatching and larval survival degree. The results showed that the combination of feed pellets ampela $50 \%$ to $50 \%$ is the right combination for catfish spawners could increase fecundit, hatching and larval survival degree. While the combination of feed pellets ampela $75 \%$ to $25 \%$ is the right combination to increase length of rematuration of catfish spawners.
\end{abstract}

Key words: chicken gizzar, catfish spawners, pellet

\begin{abstract}
ABSTRAK
Saat ini budidaya ikan lele merupakan salah satu pilihan masyarakat, karena dipicu oleh banyaknya permintaan ikan lele. Namun dalam kegiatan budidaya yang dilakukan oleh masyarakat terkadang tidak memperhatikan aspek kualitas induk ikan lele tersebut. Kualitas induk ini juga tergantung dari kualitas pakan yang diberikan. Oleh karena itu, diperlukan pakan dengan kualitas yang baik agar menghasilkan induk lele yang berkualitas baik. Tujuan dari penelitian ini adalah untuk mengetahui dosis optimum komposisi penambahan ampela ayam dalam pakan terhadap performa reproduksi induk ikan lele. Pakan yang diberikan selama pematangan gonad induk ikan lele adalah pakan apung komersil merk Hi-Pro-Vite 781 dengan kandungan protein 30\%-33\% yang dikombinasikan dengan ampela ayam yang direbus. Perlakuan kombinasi pakan yang digunakan adalah: 1. Kontrol (Pellet), 2. 25\% pellet, 75\% ampela, 3. 50\% pellet, 50\% ampela, dan $4.75 \%$ pellet, $25 \%$ ampela. Parameter yang diamati adalah fekunditas, lama rematurasi, derajat penetasan, dan derajat kelangsungan hidup larva. Hasil yang diperoleh memperlihatkan bahwa pakan kombinasi ampela $50 \%$ dengan pellet $50 \%$ merupakan kombinasi yang tepat untuk dapat meningkatkan fekunditas induk lele serta derajat penetasan dan derajat kelangsungan hidup larva yang dihasilkannya. Sedangkan pakan kombinasi ampela $75 \%$ dengan pellet $25 \%$ merupakan kombinasi yang tepat untuk meningkatkan rematurasi induk lele.
\end{abstract}

Kata Kunci: ampela ayam, induk ikan lele, pellet

\section{PENDAHULUAN}

Ikan lele merupakan salah satu ikan budidaya yang populer di Indonesia. Saat ini budidaya ikan lele merupakan salah satu pilihan masyarakat, karena dipicu oleh banyaknya permintaan ikan lele. Selain itu, masyarakat banyak melakukan budidaya ikan lele karena lele mudah untuk dibudidayakan dan 
memliki toleransi yang tinggi terhadap lingkungan.

Namun dalam kegiatan budidaya yang dilakukan oleh masyarakat terkadang tidak memperhatikan aspek kualitas induk ikan lele tersebut, padahal kualitas induk yang digunakan sangat penting dalam kegiatan budidaya ikan lele ini. Kualitas induk ini juga tergantung dari kualitas pakan yang diberikan. Pakan memegang peranan penting dalam proses keberhasilan usaha budidaya perikanan. Kualitas pakan yang baik menentukan kualitas ikan yang dihasilkan (Zonneveld et al, 1991). Pakan mempengaruhi laju pertumbuhan, produksi, kesehatan, kelangsungan hidup, dan reproduksi ikan (Samsudin dan Djajasewaka, 2009).

Selain itu, kecepatan pematangan gonad juga merupakan faktor penting dalam budidaya. Pertumbuhan dan pematangan gonad terjadi apabila terdapat kelebihan energi yang diperoleh dari makanan untuk pertumbuhan tubuh (Elliot, 1979 dalam Samsudin, 2009). Pakan induk harus memenuhi kebutuhan energi ikan sehingga tidak meneyebabkan oosit mengalami atresia (Wooton, 1979; Hardjamulia dan Atmawinata, 1986). Oleh karena itu, diperlukan pakan dengan kualitas yang baik agar menghasilkan induk lele yang berkualitas baik. Tujuan dari penelitian ini adalah untuk mengetahui dosis optimum komposisi penambahan ampela ayam dalam pakan terhadap performa reproduksi induk ikan lele.

\section{METODE}

Pakan yang diberikan selama pematangan gonad induk ikan lele adalah pakan apung komersil merk HiPro-Vite 781 dengan kandungan protein 30\%-33\% yang dikombinasikan dengan ampela ayam yang direbus. Pemberian pakan dilakukan dengan frekuensi 3 kali sehari yaitu pada pagi hari pukul 07.00 , 11.00 dan sore hari pukul 16.00 WIB, sebanyak 5\% dari bobot total induk dengan kandungan gizi: Protein 33\%, Lemak 5\%, Serat 6\%, Abu $8 \%$ dan Kadar air 13\%. Perlakuan kombinasi pakan yang digunakan adalah:

$$
\begin{array}{ll}
\text { - } & \text { 1. Kontrol (Pellet) } \\
\text { - } & 2.25 \% \text { pellet, } 75 \% \text { ampela } \\
\text { - } & 3.50 \% \text { pellet, } 50 \% \text { ampela } \\
\text { - } & 4.75 \% \text { pellet, } 25 \% \text { ampela }
\end{array}
$$

Setiap perlakuan diberikan kepada 8 ekor induk lele betina dg berat ratarata $1,5 \mathrm{~kg}$.

Parameter yang diamati pada penelitian ini adalah :

1. Lama rematurasi (pematangan kembali)

Lama rematurasi dihitung dari sampling awal gonad calon induk lele betina sampai dengan keadaan gonad berisi $90 \%$ telur TKG IV. Sampling gonad ini dilakukan dengan menggunakan kateter.

2. Fekunditas

Fekunditas dihitung dengan metode sampling dari jumlah telur yang dihasilkan per-kilogram berat induk.

3. Derajat Penetasan

Derajat Penetasan dihitung dengan metode sampling. Rumus yang digunakan adalah :

Derajat Penetasan $=$ $\frac{\text { Jumlah telur menetas }}{\text { Total jumlah telur }} \times 100 \%$

4. Derajat Kelangsungan Hidup Larva Derajat Kelangsungan Hidup Larva dihitung dengan hari ke-30 pemeliharaan dengan metode sampling. Rumus yang digunakan adalah :

Derajat Kelangsungan Hidup Larva

$$
\frac{=}{\text { Jumlah larvahidup (harike-30) }} \times 100 \%
$$




\section{HASIL DAN PEMBAHASAN}

Dari Tabel 1 dapat dilihat bahwa perlakuan kombinasi pakan ampela 50 $\%$ dengan pellet $50 \%$ memberikan nilai yang tertinggi dari aspek fekunditas, derajat penetasan, dan derajat kelangsungan hidup larva. Dari aspek fekunditas, nilai yang didapat dari perlakuan ini berbeda nyata dengan kontrol dan perlakuan kombinasi pakan ampela $25 \%$ dengan pellet $75 \%$, sedangkan dengan perlakuan kombinasi pakan ampela $75 \%$ dengan pellet $25 \%$ nilainya tidak berbeda nyata. Nilai fekunditas ini kemungkinan dipengaruhi oleh kandungan vitamin dan mineral yang terdapat dalam pakan induk. Vitamin dan mineral dalam pakan induk mempunyai peran yang penting dalm meningkatkan kualitas telur termasuk fekunditas induk (Djajasewaka et al, 2009).

Dari aspek rematurasi, perlakuan kombinasi pakan ampela $75 \%$ dengan pellet $25 \%$ memiliki nilai yang terbaik dan berbeda nyata dengan perlakuan lainnya. Pada perlakuan tersebut induk lebih cepat matang gonad dibandingkan perlakuan lainnya. Hal ini kemungkinan disebabkan kandungan lemak yang terdapat dalam pakan ampela, sehingga semakin besar dosisnya maka akan semakin cepat merangsang pematangan gonad induk. Lemak mempunyai peranan penting bagi pertumbuhan ikan baik sebagai sumber energi, pelarut beberapa vitamin larut lemak dan sebagai pembentuk beberapa jenis hormon. Pemenuhan lemak dan asam lemaknya dalam jumlah cukup akan membantu meningkatkan proses pembentukan telur dan kualitas benih yang dihasilkan (Suhenda et al, 2008),

Dari aspek derajat penetasan, perlakuan pemberian kombinasi pakan ampela tidak memberikan pengaruh yang berbeda nyata. Namun nilai yang terbaik tetap diperoleh pada perlakuan kombinasi pakan ampela $50 \%$ dengan pellet $50 \%$. Sedangkan dari aspek derajat kelangsungan hidup larva, nilai terbaik ada pada perlakuan kombinasi pakan ampela $50 \%$ dengan pellet $50 \%$. Nilai ini tidak berbeda nyata dengan perlakuan kombinasi pakan ampela 75 $\%$ dengan pellet $25 \%$. Dari kedua aspek tersebut, dapat diketahui bahwa pakan yang diberikan sudah memberikan nutrisi yang cukup bagi induk lele, hal ini dapat dilihat dari tingginya derajat penetasan dan derajat kelangsungan hidup larva. Nutrisi dalam pakan memiliki peran penting dalam usaha pematangan gonad ikan, salah satu faktor yang mempengaruhinya yaitu lemak pakan. Berdasarkan penelitian Sink dan Lochman (2008) dalam Samsudin dan Djajasewaka (2009), penggunaan lipid dalam pakan sebesar 6-10 \% dapat meningkatkan keragaan reproduksi ikan. Lemak dan komposisi asam lemak pakan induk merupakan faktor utama untuk mendukung keberhasilan reproduksi induk dan tingkat kelangsungan hidup benih yang dihasilkannya (Izquierdo et al, 2001).

Tabel 1. Fekunditas, Rematurasi, Derajat Penetasan, dan Derajat Kelangsungan Hidup Larva Ikan Lele pada beberapa persentase pemberian pakan ampela yang berbeda

\begin{tabular}{lcccc}
\hline \multicolumn{1}{c}{ Parameter } & Ampela 0 \% & Ampela 25 \% & Ampela 50 \% & Ampela 75 \% \\
\hline -Fekunditas & $22579 \pm 2497$ & $22745 \pm 2334$ & $29189 \pm 764$ & $27683 \pm 1122$ \\
(butir/kg) & & & & \\
-Rematurasi (hari) & $65 \pm 3$ & $59 \pm 3$ & $56 \pm 4$ & $46 \pm 3$ \\
-Derajat & $70,91 \pm 1,627$ & $72,56 \pm 6,377$ & $79,35 \pm 4,191$ & $78,52 \pm 3,115$ \\
$\begin{array}{l}\text { Penetasan (\%) } \\
\text {-Derajat }\end{array}$ & $76,20 \pm 8,148$ & $78,61 \pm 5,862$ & $90,64 \pm 4,947$ & $86,64 \pm 1,895$ \\
$\begin{array}{l}\text { Kelangsungan } \\
\text { Hidup Larva (\%) }\end{array}$ & & & & \\
\hline
\end{tabular}




\section{Fekunditas}

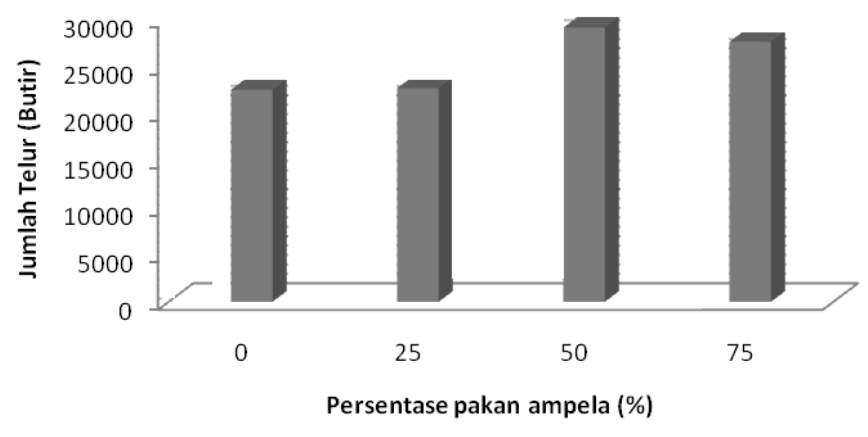

Gambar 1. Diagram Batang Fekunditas

\section{Rematurasi}

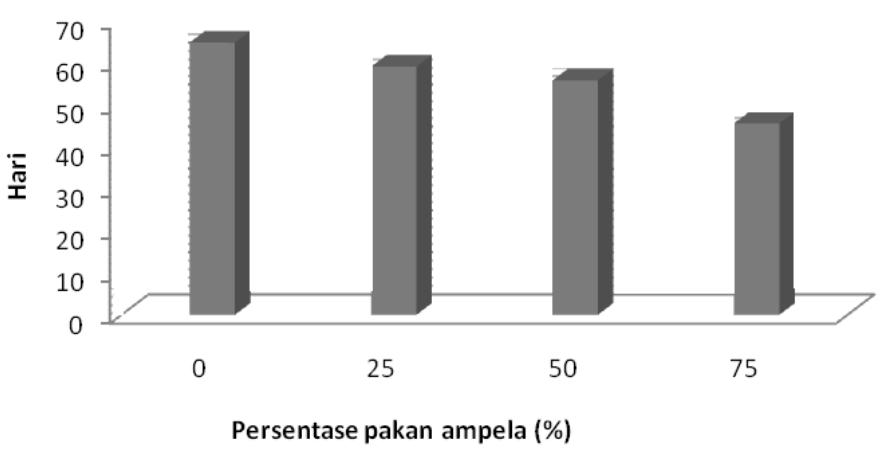

Gambar 2. Rematurasi Induk Ikan Lele

\section{Derajat Penetasan}

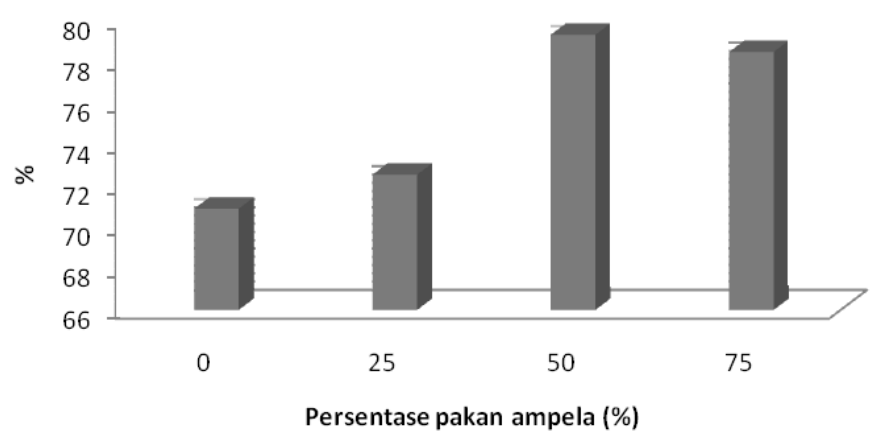

Gambar 3. Derajat Penetasan Larva yang dihasilkan 


\section{Derajat Kelangsungan Hidup Larva}

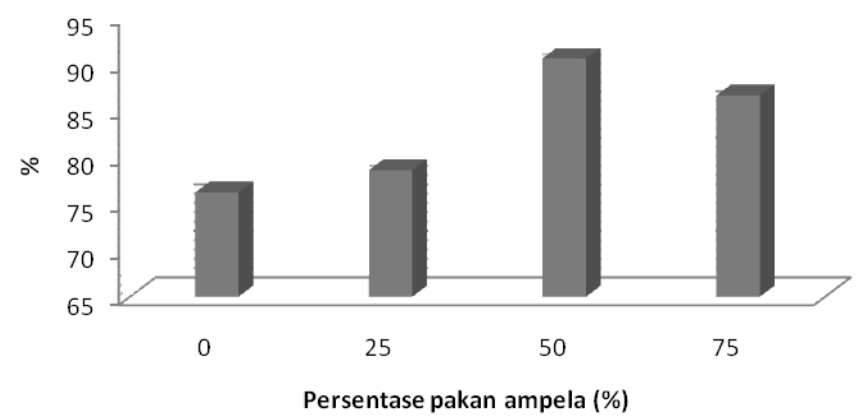

Gambar 4. Derajat Kelangsungan Hidup Larva yang dihasilkan

\section{KESIMPULAN}

Dari hasil penelitian ini dapat diambil kesimpulan bahwa pakan kombinasi ampela $50 \%$ dengan pellet $50 \%$ merupakan kombinasi yang tepat untuk dapat meningkatkan fekunditas induk lele serta derajat penetasan dan derajat kelangsungan hidup larva yang dihasilkannya. Sedangkan pakan kombinasi ampela $75 \%$ dengan pellet $25 \%$ merupakan kombinasi yang tepat untuk meningkatkan rematurasi induk lele.

\section{DAFTAR PUSTAKA}

Djajasewaka, H., A. Wakhid, dan R. Samsudin. 2009. Perbaikan Pakan Induk terhadap Peningkatan Kualitas Telur, Benih, dan Ketahanan Penyakit Ikan mas (Cyprinus carpio). Laporan Penelitian Hibah Departemen Pendidikan Nasional.

Hardjamulia dan Atmawinata, 1986. Teknik Hipofisasi Beberapa Jenis Ikan Air Tawar. Dalam Fuad Cholik (Ed.). Pros. Lokakarya Nasional Teknologi Tepat Guna Bagi Pengembangan Perikanan Budidaya Air Tawar. Bogor 28-31 Juni 1980. Balai Penelitian Perikanan Air Tawar Bogor.
Izquierdo, M.S., H Fernandez, Palacios dan A. J. Tacon. 2001. Effect of Broodstock Nutrition on Reproductive Performance of Fish. Aquaculture 197: 25-42.

Samsudin R., dan H. Djajasewaka, 2009. Percepatan Waktu Rematurasi Gonad Ikan Nilem Dengan Perbaikan Kualitas Pakan Induk. Laporan Seminar Hasil Riset T.A. 2009. Balai Riset Perikanan Budidaya Air Tawar, Bogor.

Suhenda, N., dan R. Samsudin. 2007. Pematangan Gonad Ikan Baung melalui Perbaikan Pakan Induk (Dempond). Laporan Seminar Hasil Riset T.A. 2007. Balai Riset Perikanan Budidaya Air Tawar, Bogor.

Wooton, R. J. 1979. Energy Cost Production and Environmental Determinent of Fecundity on Teleost Fish. In : P.J. Miller (Ed.). Fish Phenology Anabolic Adaptive in Teleost. 133-159. Academy Press inc. London.

Zonneveld, N., E. A. Huisman, J. H. Boon. 1991. Prinsip-prinsip Budidaya Ikan. PT. Gramedia Pustaka Utama. 318. 